\title{
Aplicação de Redes Neurais Artificiais na Construção de Modelos de Fragilidade Ambiental
}

\author{
Christiane Spörl ${ }^{1}$ \\ Emiliano G. Castro² \\ Aílton Luchiari ${ }^{3}$
}

\begin{abstract}
Resumo: Este artigo aborda o desafio da modelagem da fragilidade ambiental, que implica em, além de compreender a intrínseca e dinâmica relação existente entre as componentes físicas, bióticas e sócio-econômicas dos sistemas ambientais, também tentar traduzir esse conhecimento em modelos matemáticos. Para ilustrar esta dificuldade foram apresentados e comparados os resultados gerados por dois modelos empíricos de fragilidade ambiental, amplamente utilizados (CREPANI et al. 2001 e ROSS, 1994). Estes dois modelos foram aplicados em duas áreas-teste, com resultados bastante divergentes. Neste contexto de incertezas, foi testada a viabilidade e a confiabilidade de uma nova ferramenta que pode ser aplicada na elaboração de modelos de fragilidade ambiental, as redes neurais artificiais. Para tanto, foram empregados os conhecimentos e experiências de especialistas na área em questão. Os resultados comprovaram que é possivel emular, com razoável confiabilidade, o padrão de avaliação de especialistas na definição da fragilidade dos sistemas ambientais, eliminando assim a arbitrariedade e a subjetividade do processo de elaboração de modelos de fragilidade ambiental. Este trabalho não propõe um novo modelo, mas sim uma metodologia para a construção de modelos utilizando redes neurais artificiais, dando um primeiro passo em busca de novas técnicas, às vezes temidas pelos geógrafos, mas necessárias para a evolução da ciência geográfica.
\end{abstract}

Palavras-Chave: Fragilidade ambiental, modelos e redes neurais artificiais.

Abstract This paper deals with the challenge in modeling environmental fragility, which implies not only the understanding of the intrinsic and dynamic relationship between the physical, biotic and socio-economic components of environmental systems, but also in trying to translate this knowledge in mathematical models. In order to shed some light on this difficulty, the results generated by two empirical models of environmental fragility were presented and compared, models that are widely used (CREPANI et al. 2001 and ROSS, 1994). These two models were applied in two thesis-areas with very diverging results. Within this context of uncertainties, this paper tested the feasibility and reliability of a new tool that can be applied in the elaboration of environmental fragility models, the artificial neural networks. For that, were used the knowledge and experience of specialists in this area. The results proved that it is possible to emulate, with reasonable reliability, the evaluation pattern of specialists in the definition of environmental systems fragility, eliminating in this way, the arbitrariness and subjectivity in the elaboration process of environmental fragility models. This work does not present a new model, but rather a methodology for the construction of models using artificial neural networks, taking the first step in the search of new techniques, sometimes feared by the geographers, however necessary for the evolution of the geographic science.

Key-Words: Environmental fragility, models and artificial neural networks.

\footnotetext{
${ }^{1}$ Faculdade de Filosofia, Letras e Ciências Humanas - USP. chsporl@usp.br

${ }^{2}$ Escola Politécnica - USP. emiliano@usp.br

${ }^{3}$ Faculdade de Filosofia, Letras e Ciências Humanas - USP. aluchiar@usp.br
} 


\section{INTRODUÇÃO}

Os estudos relativos à fragilidade dos ambientes são de significativa importância para o planejamento territorial, pois se trata de um instrumento cuja finalidade é identificar e analisar os ambientes em função de seus diferentes níveis de vulnerabilidade, principalmente frente aos processos erosivos, aos deslizamentos de encostas, ao assoreamento de cursos de água e às inundações.

Para se obter um panorama das condições de vulnerabilidade do sistema é necessário, segundo Ross (1994), realizar um estudo integrado dos elementos componentes do estrato geográfico que dão suporte à vida animal e ao homem, os quais analisados e interrelacionados geram um produto analítico-sintético que retrata a situação da área de estudo. Esta análise integrada permite obter um diagnóstico das diferentes categorias hierárquicas da fragilidade dos ambientes naturais, resultando na carta síntese de Fragilidade/Vulnerabilidade Ambiental.

A carta de fragilidade ambiental, ainda segundo Ross (1991), auxilia o diagnóstico-síntese que pode perfeitamente nortear as intervenções antrópicas futuras e corrigir as presentes. É, portanto, um instrumento importante no trabalho de planejamento físico territorial.

Este mapeamento da fragilidade ambiental se constitui num passo indispensável à medida que, atualmente, é cada vez mais necessário conhecer e compreender a dinâmica do sistema e as transformações dele decorrentes para subsidiar o planejamento nas definições das ações prioritárias a serem tomadas, destinadas a assegurar a qualidade dos recursos hídricos e do solo, e a conservação da biodiversidade.

Dada à importância deste tema existem diversos modelos metodológicos aplicados aos estudos da fragilidade para fins de ordenamento territorial, os quais estabelecem o grau de vulnerabilidade dos sistemas, visando promover o uso dos recursos naturais da melhor forma possível.

Dentre estes modelos empíricos podem ser citados dois modelos propostos por Ross (1994), um com apoio nos Índices de Dissecação do Relevo, e o outro com apoio nas Classes de Declividade; e ainda o modelo sugerido por Crepani et al. (2001) com apoio em Unidades Territoriais Básicas (UTBs). Os três modelos são amplamente utilizados.

Estes modelos têm como ponto comum o entendimento da inter-relação dos elementos do meio físico e biótico. Utilizam praticamente as mesmas variáveis, no entanto apresentam 
diferentes formas de calcular a vulnerabilidade, assim como "pesos" distintos para cada uma destas variáveis envolvidas na obtenção dos graus de fragilidade.

O modelo proposto por Crepani et al. (2001) trabalha com valores médios para o produto final, e Ross (1994) trabalha com o agrupamento dos índices das variáveis e adota o relevo como variável principal. As formas de cálculo para obtenção dos graus de fragilidade refletem as diferentes maneiras de ponderar a importância das variáveis avaliadas. Por exemplo, no modelo de análise proposto por Crepani et al. (2001), a utilização da média aritmética entre as variáveis pressupõe que todas elas têm a mesma importância (peso) para o estabelecimento do grau de fragilidade. No modelo de análise sugerido por Ross (1994) a variável que representa o 1 을 dígito da associação numérica determina o grau de fragilidade, enquanto que as demais variáveis apenas hierarquizam nuances desta fragilidade. Deste modo, a variável relevo (1ำ dígito) é que determina o grau de fragilidade. Sendo assim, no modelo proposto por Crepani et al. (op. cit.) todas as variáveis têm o mesmo peso, já no modelo proposto por Ross (1994) o relevo tem uma importância muito maior na definição dos graus de fragilidade do que as demais variáveis.

Como conseqüência destas diferenças técnico-operacionais os mapas sínteses resultantes da aplicação destes modelos apresentam resultados bastante divergentes, conforme exposto em Spörl (2001).

Deve-se também ressaltar que algumas pesquisas que correlacionam resultados da aplicação destes modelos de fragilidade ambiental e da investigação de campo demonstram que nem sempre os resultados são convergentes. Como exemplos, podem ser citados os trabalhos de Nakashima (1999) e de Rodrigues (1998), os quais mostram que freqüentemente os resultados dos modelos não condizem com as respostas da natureza.

Análises e comparações realizadas em Spörl (2007) demonstram que esses modelos apresentam certas deficiências. O principal problema observado está relacionado à atribuição de "pesos" às variáveis. Estes pesos devem indicar a contribuição relativa de cada uma das variáveis (relevo, solo, rocha, cobertura vegetal e clima) na determinação do grau de fragilidade de uma área.

Essas deficiências apresentadas pelos modelos são resultantes da grande dificuldade em ajustar os modelos propostos de análise da Fragilidade Ambiental de maneira a conciliá-los com os fenômenos complexos da natureza. 
Diante destas constatações surge uma incerteza na questão da confiabilidade destes modelos. Desta forma, verifica-se a necessidade de que todo modelo deve ser testado, validado e, mais importante ainda, ser falseado. Os modelos devem estar num contínuo processo de busca de erros para a sua depuração. Pode-se dizer que o objetivo mais importante é verificar sob quais condições o modelo não funciona, ou seja, verificar e comprovar quais as suas limitações.

Openshaw et al. (1997) reporta que há a necessidade de considerar a reengenharia de modelos existentes através da Computação Inteligente, a fim de explorar sua nãolinearidade, adaptabilidade, incerteza etc.

Desta forma, busca-se neste trabalho contribuir no aperfeiçoamento dos modelos de Fragilidade Ambiental e no desenvolvimento de uma nova metodologia para a elaboração de modelos aplicando-se Redes Neurais Artificiais (RNAs), onde possam ser minimizadas as limitações apresentadas nos modelos já existentes.

As Redes Neurais Artificiais (RNAs) são algoritmos computacionais que apresentam um modelo matemático inspirado na estrutura neural de organismos inteligentes tentando emular em máquinas (computadores) o funcionamento do cérebro humano, ainda que de maneira simplificada. Assim como o cérebro humano, a RNA é capaz de aprender e tomar decisões baseadas em seu próprio aprendizado. Desta forma, a RNA pode ser interpretada como um esquema de processamento capaz de armazenar conhecimento baseado em aprendizagem (experiência) e disponibilizar este conhecimento para a aplicação em questão. As RNAs são amplamente utilizadas para soluções de problemas complexos, onde o comportamento das variáveis não é rigorosamente conhecido. São utilizadas nas mais diversas áreas do conhecimento, principalmente em aplicações que envolvam reconhecimento de padrões, assim como, análise de séries temporais, diagnósticos médicos, previsões no mercado financeiro, etc.

Diante do exposto, a RNA é capaz de reconhecer padrões, ou seja, possui a capacidade de aprender por meio de exemplos e de generalizar a informação aprendida, gerando um modelo não-linear, o que torna a sua aplicação na análise espacial bastante eficiente.

O sucesso das RNAs para modelar sistemas dinâmicos em vários campos da ciência e da engenharia sugere que elas também possam ser aplicadas nos modelos de fragilidade ambiental. A utilização das RNAs na análise ambiental disponibiliza essa nova ferramenta para decisões complexas, que envolvem muitos critérios, sendo que a seleção dos critérios, 
assim como a definição de seus pesos, são avaliações arbitrárias e subjetivas, dificultando o processo de análise.

\section{OBJETIVOS}

Os principais objetivos deste estudo são gerar discussões a respeito dos métodos de construção dos modelos empíricos existentes, desenvolver e testar as redes neurais artificiais (RNAs) como uma nova alternativa metodológica para a elaboração de modelos de análise da fragilidade ambiental. Pretende-se assim testar a viabilidade e a confiabilidade desta nova ferramenta nesses modelos, adotando as seguintes etapas:

- Implementar um sistema de apoio à tomada de decisão através do reconhecimento de padrões adotados por especialistas da área de domínio, utilizando RNAs e adotando-se a metodologia proposta por Castro (1998) como base para uma nova abordagem do modelo de fragilidade ambiental;

- Testar essa nova ferramenta proposta para análise da fragilidade ambiental, as RNAs, no reconhecimento do padrão de avaliação dos especialistas consultados;

- Apresentar e aplicar os modelos empíricos existentes de fragilidade ambiental propostos por Ross (1994) e por Crepani et al. (2001) em duas áreas-teste para comparar o desempenho destes modelos em diferentes cenários;

- Comparar os modelos empíricos propostos por Ross (op. cit.) e por Crepani et al. (op. cit.) com os resultados gerados pelo treinamento das suas respectivas RNAs.

\section{MATERIAIS E MÉTODOS}

A modelagem da fragilidade ambiental é um desafio, pois apresenta duas grandes dificuldades: a primeira, é entender o comportamento das variáveis ambientais diante dos mecanismos que atuam na vulnerabilidade do sistema, e a outra, é traduzir, o mais fielmente possível, esse conhecimento para um sistema de equações matemáticas, o modelo.

Dada às propriedades e amplas possibilidades de utilização das redes neurais artificiais (RNA), esta ferramenta de Inteligência Artificial foi testada neste estudo como alternativa à 
elaboração de modelos de fragilidade ambiental, visando minimizar as limitações dos modelos já existentes.

As RNAs foram treinadas com conhecimentos extraídos a partir de simulações (realizadas através de um programa de pesquisa) de processos de escolha, assim reconhecendo e assimilando os padrões de decisão adotados pelos especialistas consultados.

Desta forma, para aplicar as RNAs nesta nova proposta metodológica foram necessárias as seguintes etapas:

- 1a etapa - compor um conjunto de treinamento para as RNAs;

- 2a etapa - aprendizado (treinamento), onde as redes aprendem por meio de exemplos;

- 3a etapa - as redes extraem as informações relevantes dos padrões de informação que Ihe são apresentados;

- 4a etapa - as redes reconhecem e assimilam os padrões de avaliação adotados pelos especialistas.

Visando obter um conjunto de treinamento a ser aplicado nas RNAs foram utilizados alguns programas especialmente desenvolvidos para uma pesquisa junto aos entrevistados (especialistas). Estes programas serviram como ferramentas para atribuir uma escala às notas das alternativas e aos pesos de cada variável selecionada (declividade dominante, solos, rochas, cobertura vegetal/uso da terra e intensidade pluviométrica), conforme os critérios de avaliação de cada entrevistado.

Estes programas foram apresentados a seis especialistas, inclusive Crepani e Ross (autores dos dois modelos empíricos também analisados neste trabalho), na forma de simulações onde os mesmos foram requisitados a fazer várias avaliações comparativas sempre entre duas alternativas ou cenários. Sem essa valiosa colaboração dos especialistas, certamente esse trabalho não teria credibilidade.

Para aplicação destas simulações foram utilizados programas desenvolvidos especificamente para esta finalidade, onde foram apresentadas aos especialistas todas as combinações de valores (dois a dois) das alternativas frente as variáveis em estudo. Em cada combinação, o especialista foi requisitado a efetuar uma avaliação comparativa. Para escalonar as alternativas na avaliação global foi adotado o mesmo procedimento.

Este procedimento permite realizar sucessivas comparações para determinar uma espécie de ranking entre os elementos avaliados, sendo que estes dados compilados constituíram a 
base de informações para o reconhecimento dos padrões de análise de cada especialista consultado.

Estas simulações foram responsáveis por compor um conjunto de treinamento para as RNAs, sendo executadas a partir de três diferentes programas adaptados para este trabalho. Os programas desenvolvidos são:

\section{Pesquisa de Calibração}

Este programa tem como finalidade familiarizar e treinar os entrevistados a utilizar o sistema de avaliação implementado, conforme apresentado na Figura 01.

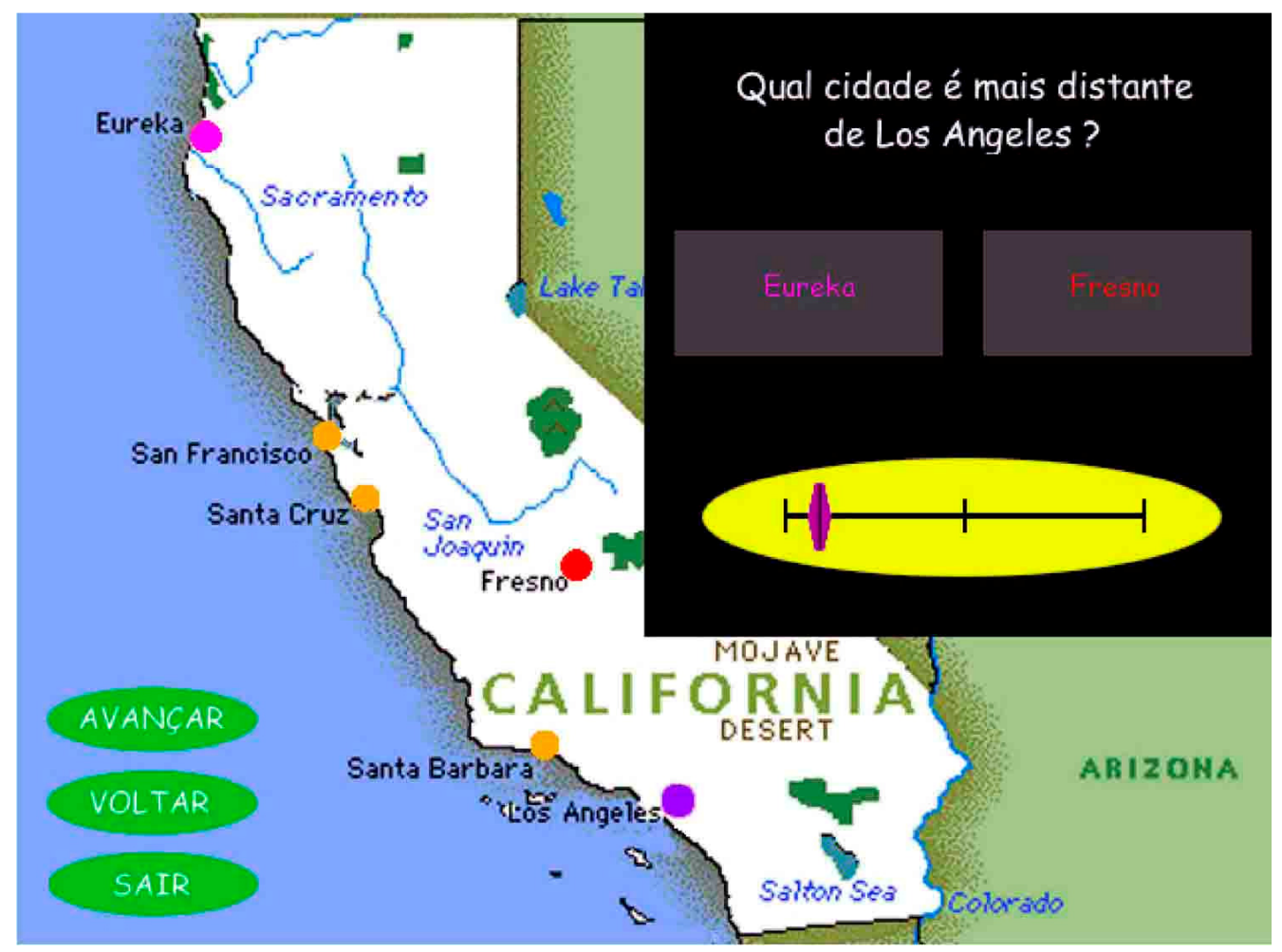

FIGURA 01 - Exemplo de Avaliação Comparativa da Pesquisa de Calibração

Esta primeira avaliação objetiva calibrar o programa de acordo com o padrão de análise de cada especialista.

\section{Pesquisa de Escalonamento de Variáveis}

Neste programa é realizada uma pesquisa de avaliação semelhante à de Calibração com a diferença de que nesta etapa o entrevistado, já familiarizado com o método, avalia o 
conjunto de valores de cada critério referente à fragilidade para obter o que foi denominado neste trabalho como "escalonamento" de variáveis, conforme apresentado na Figura 02.

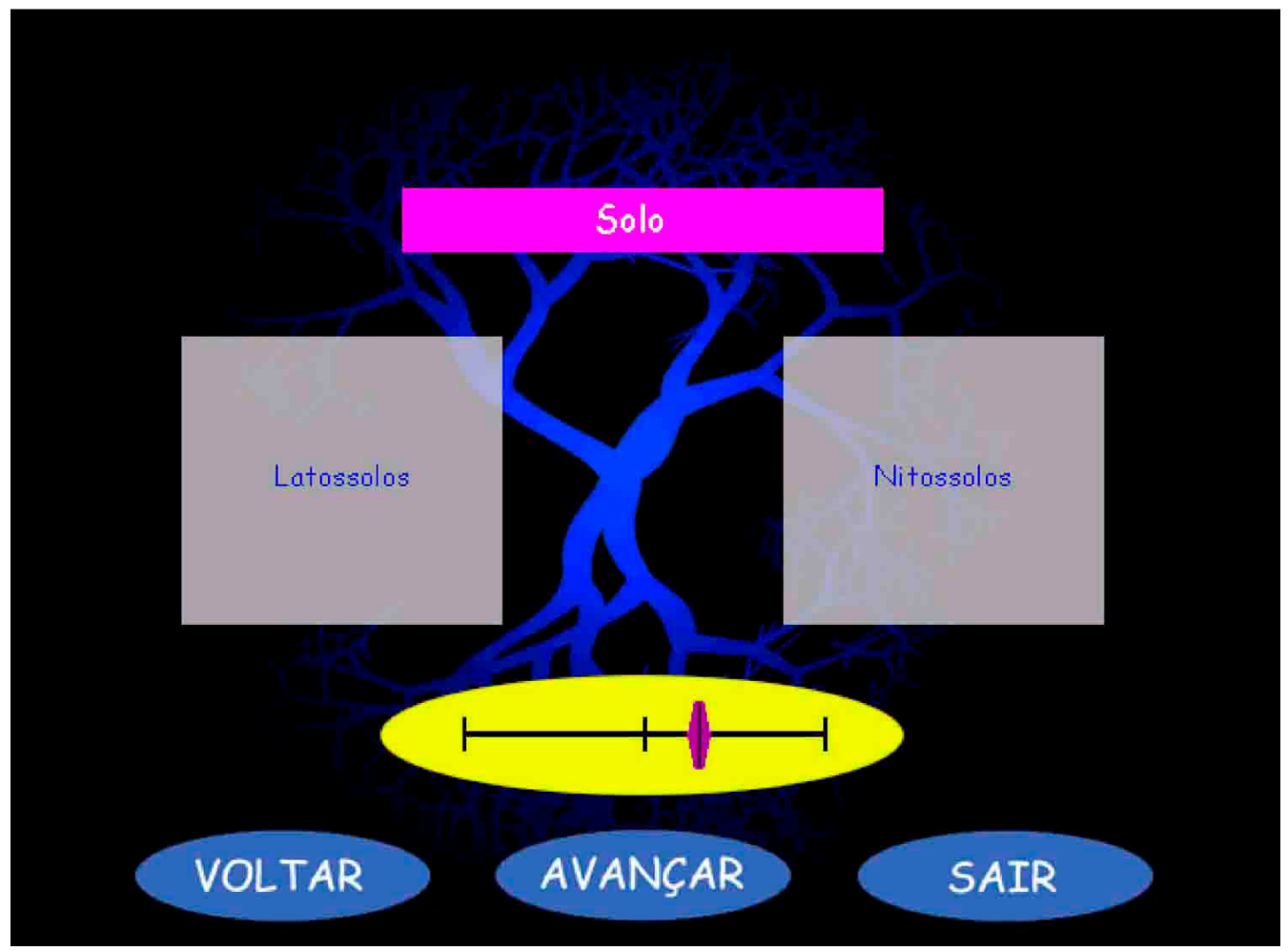

FIGURA 02 - Avaliação Comparativa da Variável Solo

\section{Pesquisa de Avaliação de Cenários}

Nesta etapa os especialistas, ao invés de comparar apenas as variáveis individualmente, são requisitados a efetuar comparações mais complexas onde são apresentadas simultaneamente todas as variáveis. Em cada uma destas simulações são apresentados dois diferentes cenários para serem comparados quanto aos seus graus de fragilidade, conforme apresentado na Figura 03.

Os resultados das comparações realizadas pelos especialistas durante a aplicação destes três programas geraram uma base de dados. Estes dados foram separados em dois conjuntos distintos. Parte dos dados foi aplicada no treinamento da RNA (conjunto de treinamento), e a outra parte na realização de testes de desempenho, importantes para verificar se as redes treinadas estavam realmente assimilando (reconhecendo) o padrão de avaliação utilizado pelo especialista. 


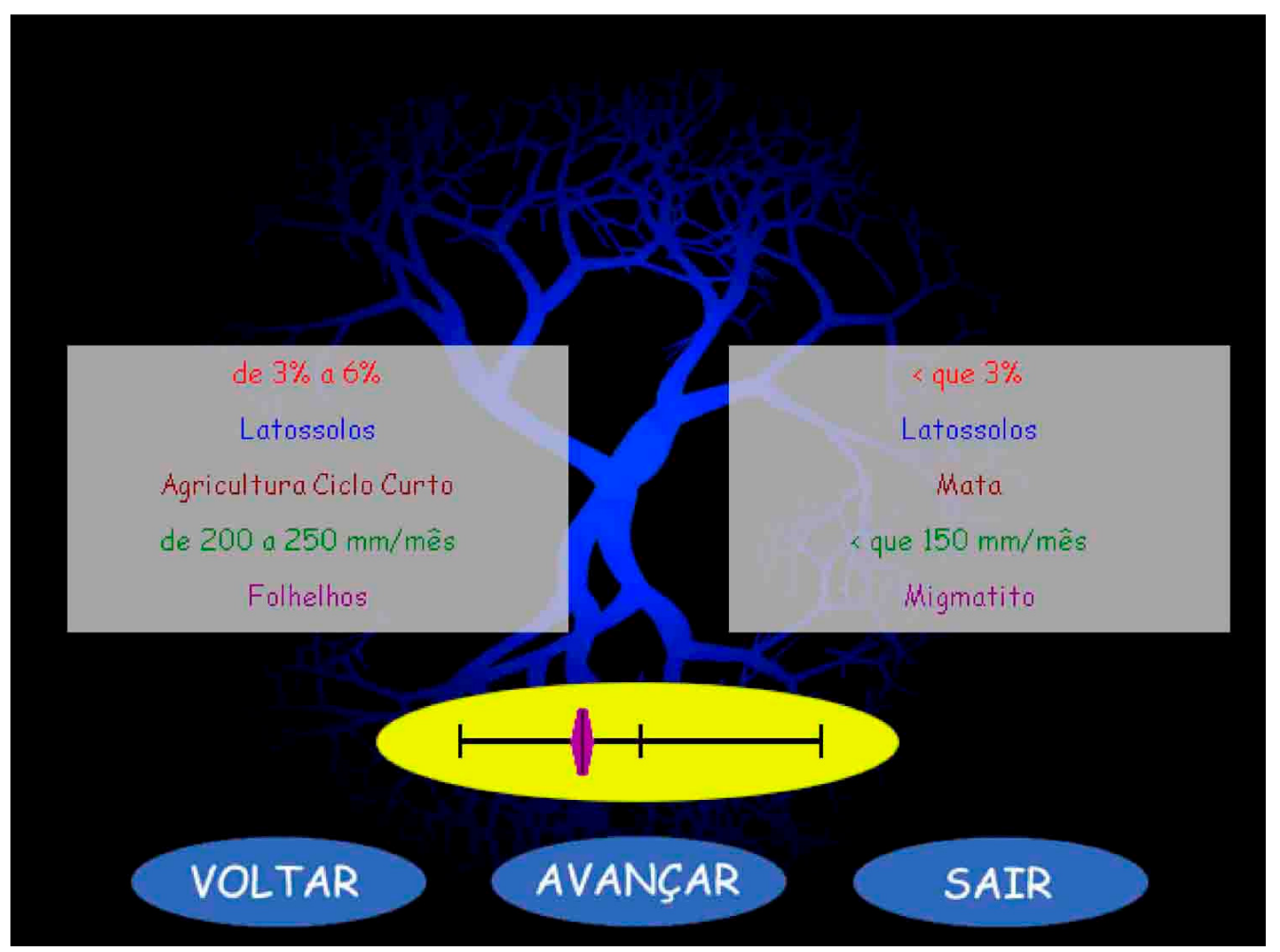

FIGURA 03 - Avaliação comparativa de dois cenários hipotéticos

Durante a fase de treinamento, as redes armazenaram vários exemplos de como o especialista "hierarquiza" ou avalia o grau de interferência de cada uma das variáveis (declividade dominante, solos, rochas, uso da terra/cobertura vegetal e intensidade pluviométrica) e suas respectivas alternativas, com maiores ou menores intensidades, na vulnerabilidade do sistema. Desta forma, a RNA foi capaz de capturar o padrão de análise de cada um dos especialistas consultados.

Finalizado o treinamento da RNA foi então realizada a verificação ou teste, alguns dados que não fizeram parte do treinamento foram testados para verificar o desempenho do aprendizado da rede. Essa verificação mediu os níveis de acerto da rede.

Na seqüência foram gerados os resultados finais simulados pelas RNAs com base no reconhecimento do padrão de avaliação de cada especialista. Ou seja, foram elaborados os mapas de fragilidade/vulnerabilidade resultantes das RNAs treinadas.

Desta forma, pode-se considerar que os modelos existentes (CREPANI et al., 2001 e ROSS, 1994), são baseados na composição de variáveis de diferentes importâncias relativas. Estas 
importâncias (pesos) são fornecidas empiricamente pelos próprios autores, enquanto neste estudo elas são os resultados obtidos através do treinamento das redes neurais artificiais.

Para fins comparativos, também foram avaliados neste estudo, para as mesmas áreas-teste, os modelos já consagrados propostos por Ross (1994) e por Crepani et al. (2001).

Estas áreas foram selecionadas em função de suas diferentes características físicas e bióticas, principalmente pela grande variabilidade do relevo. Só assim será possível testar a capacidade preditiva dos modelos em diferentes cenários.

- Área-teste 1 - a zona de contato entre a Depressão Periférica Paulista e o Planalto Atlântico, com altitudes variando entre 680 e 1620 metros. Abrange terras dos municípios de Águas da Prata (SP), São João da Boa Vista (SP), pequena faixa de Vargem Grande do Sul (SP) e parte do município de Poços de Caldas (MG).

- Área-teste 2 - Médio Vale do Paraíba e Serra da Mantiqueira, com altitudes variando entre 540 e 1980 metros. Abrange parte dos territórios dos municípios de Campos do Jordão, Monteiro Lobato, Santo Antônio do Pinhal, São Bento do Sapucaí, Pindamonhangada e Tremembé.

A espacialização destas áreas-teste é apresentada na Figura 04.

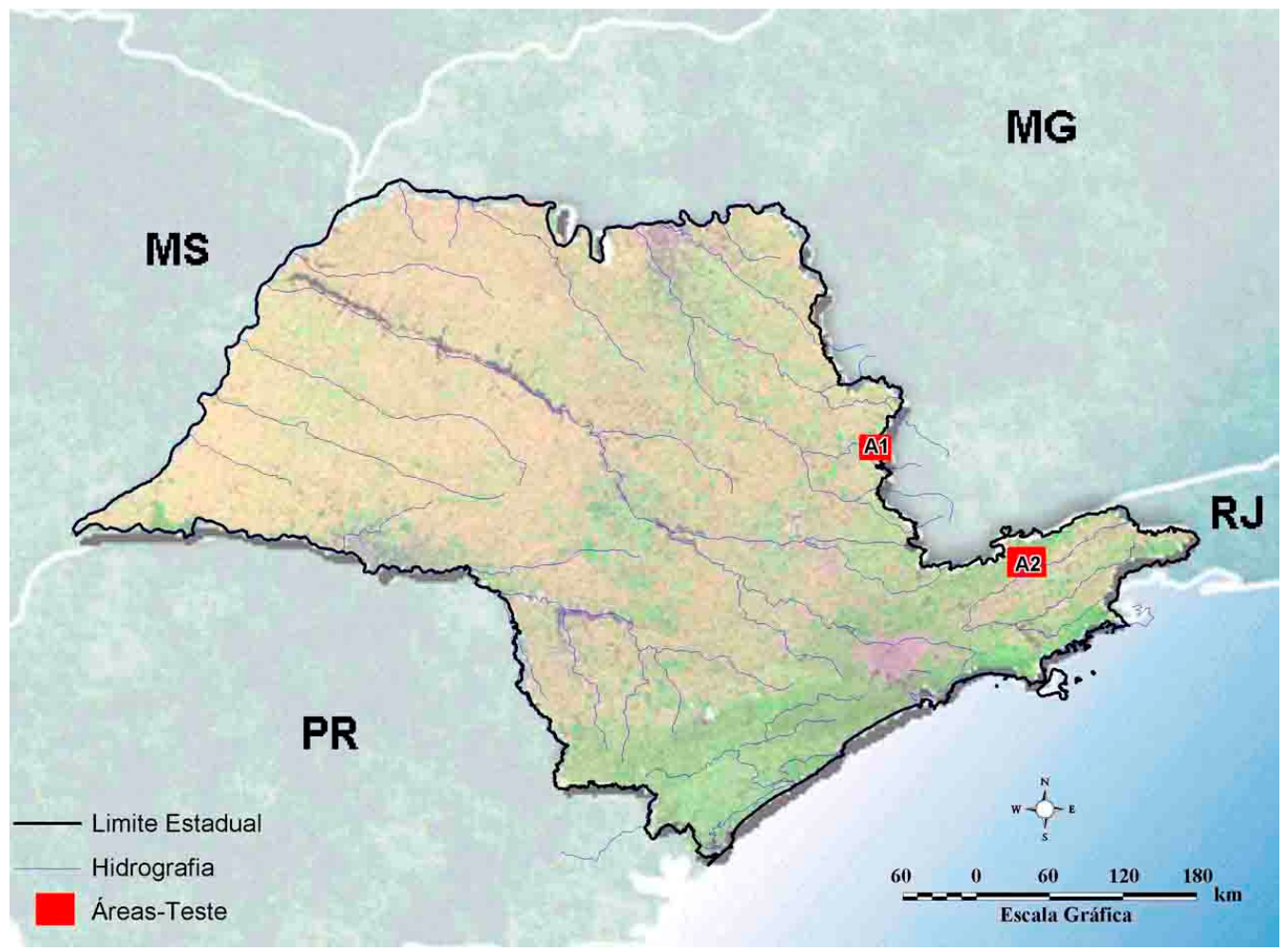

FIGURA 04 - Localização das Áreas-Teste 


\section{RESULTADOS}

Os resultados desta pesquisa podem ser apresentados em duas etapas:

- 1a etapa - apresenta o desempenho de aprendizado da rede treinada com os dados dos seis especialistas convidados;

- 2a etapa - apresenta uma avaliação comparativa entre os modelos empíricos (CREPANI et al., 2001 e ROSS, 1994) e os modelos gerados pelas RNAs treinadas com dados extraídos destes mesmos especialistas, Crepani e Ross.

Após treinamento da RNA foi averiguada a eficácia do padrão assimilado pela rede comparando-se o resultado que a rede forneceu a esse conjunto de entradas com as saídas conhecidas, ou seja, o conjunto de teste.

A partir da comparação entre os valores esperados e os valores calculados foi possível avaliar os coeficientes de correlação. Este coeficiente demonstra o desempenho de aprendizado da rede, ou seja, a eficiência das RNAs em reconhecer o padrão de avaliação dos especialistas.

O coeficiente de correlação é a medida do grau de associação entre duas variáveis a partir de uma série de observações. Determina o grau de precisão do modelo. Pode indicar correlação positiva $(r=1)$, negativa $(r=-1)$ ou não associação dos dados $(r=0)$. Na correlação positiva à medida que o valor calculado cresce o valor esperado também cresce; na correlação negativa à medida que estes valores calculados crescem, os esperados decrescem. Quanto maior o valor de " $r$ " mais forte é a associação entre estes valores. No outro extremo, se $r=0$, é sinal de que não existe nenhuma associação entre os valores calculados e esperados.

Na Tabela 01 são apresentados os coeficientes de correlação dos testes das RNAs de cada um dos seis especialistas convidados (valores esperados $x$ valores calculados).

Tabela 01 - Coeficiente de correlação dos testes das RNAs

\begin{tabular}{cc}
\hline Especialista & Coeficiente de Correlação \\
\hline A & 0,62 \\
B & 0,89 \\
C & 0,95 \\
D & 0,97 \\
E & 0,72 \\
F & 0,88 \\
\hline
\end{tabular}


Conforme observado na Tabela 01 verifica-se que as RNAs de todos os especialistas obtiveram um coeficiente de correlação satisfatório, podendo ser classificados como de bom à excelente desempenho (correlação de moderada a forte).

Para entender as convergências e divergências entre os modelos empíricos (CREPANI et al., 2001 e ROSS, 1994) e os modelos gerados pelas RNAs com dados extraídos destes mesmos especialistas foram realizadas comparações, conforme apresentado a seguir:

- Modelo Crepani et al. (2001) X Modelo Ross (1994)

- Modelo Crepani et al. (2001) x Modelo RNA Crepani

- Modelo Ross (1994) x Modelo RNA Ross

- Modelo RNA Crepani x Modelo RNA Ross

\section{Modelo Crepani et al. (2001) x Modelo Ross (1994)}

Quando comparados os modelos propostos por Crepani et al. (2001) e por Ross (1994) verificam-se as grandes divergências apresentadas, principalmente na Área-teste 2, como observado nas Figuras 05 e 06. Nestas figuras os mapas simplificados deixam claras as convergências e divergências entre os modelos, indicando em vermelho onde não houve acordo entre os resultados dos dois modelos e em verde onde houve acordo.
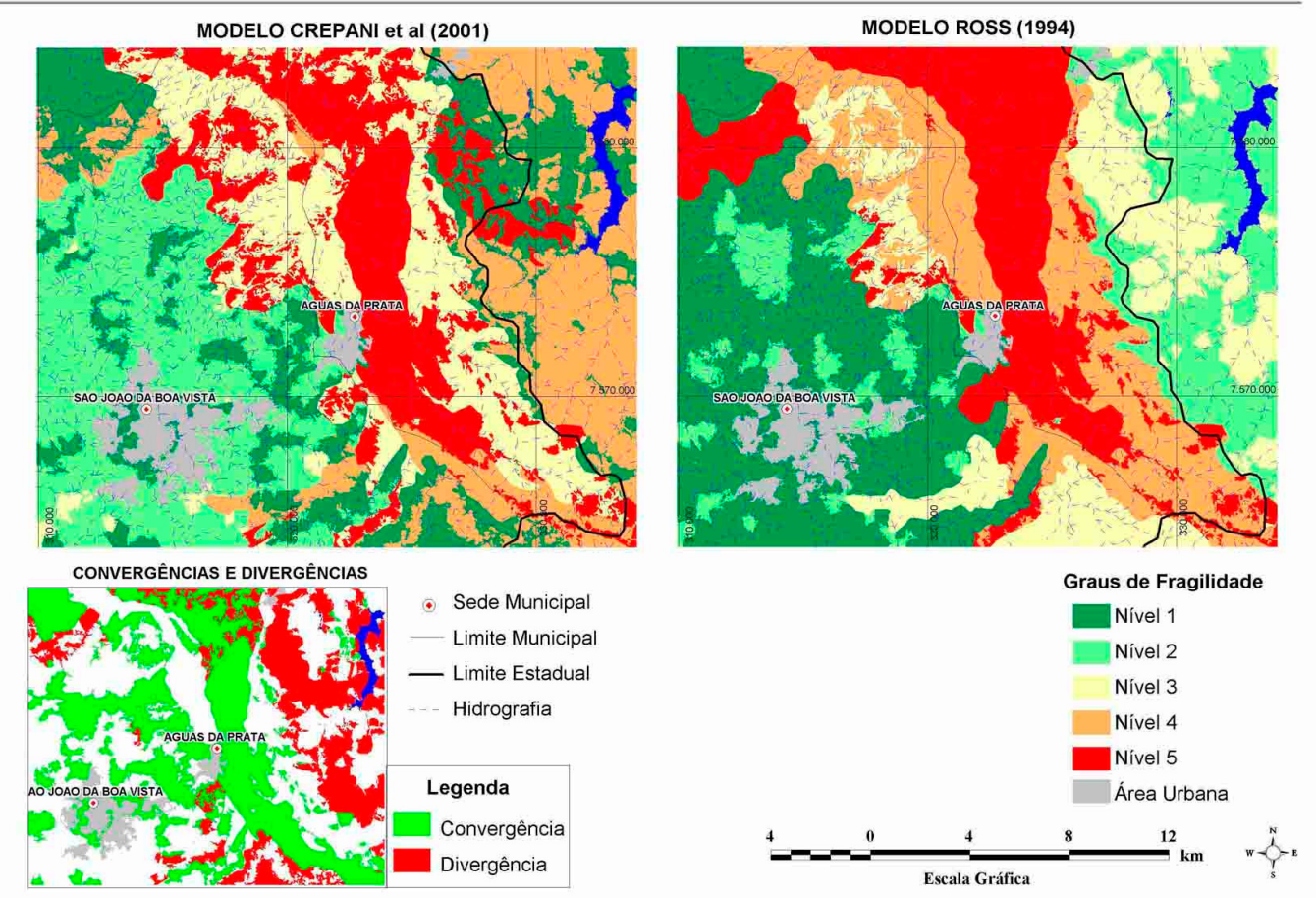

FIGURA 05 - Comparação Modelo Crepani x Modelo Ross - Área-Teste 1 


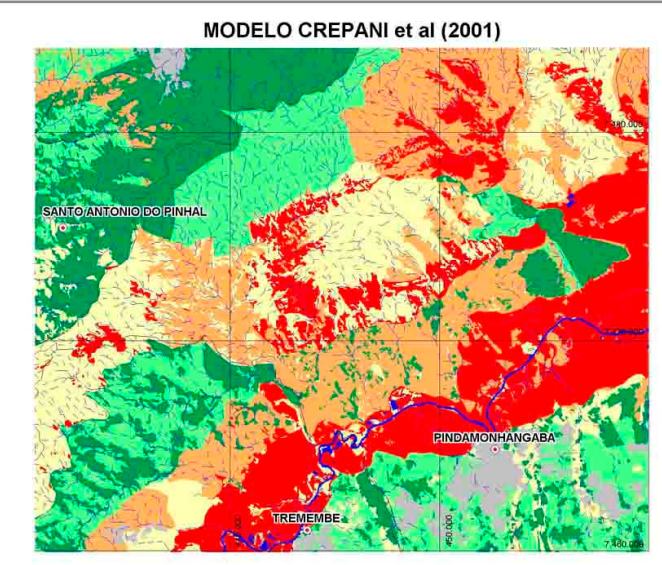

CONVERGÊNCIAS E DIVERGÊNCIAS

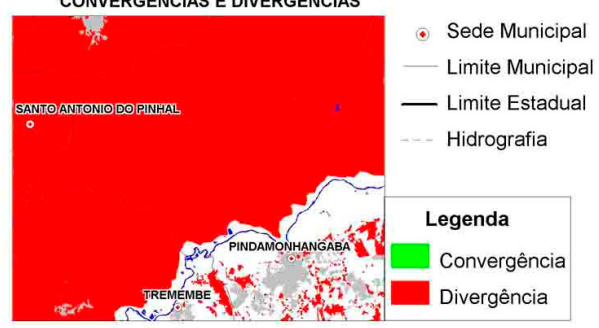

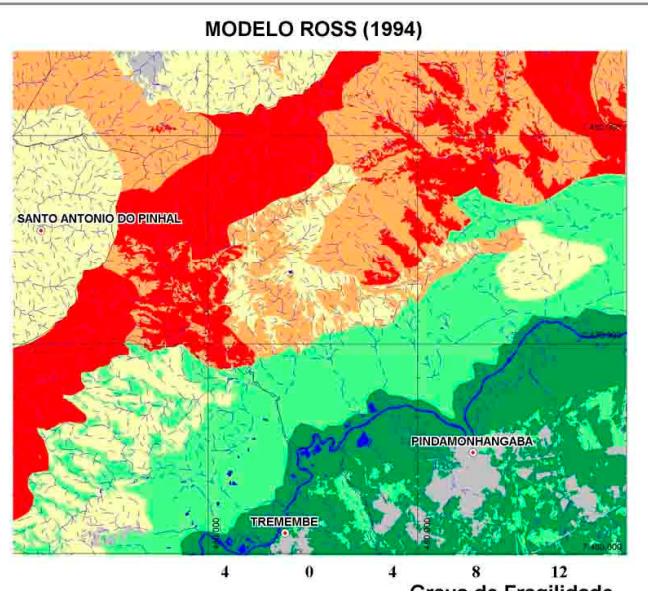

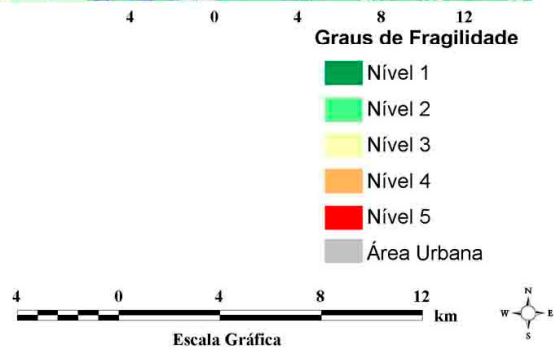

FIGURA 06 - Comparação Modelo Crepani x Modelo Ross - Área-Teste 2

As grandes divergências entre os modelos foram confirmadas pelos coeficientes de correlação calculados para verificar o grau de associação entre estes dois modelos. Os coeficientes calculados são $r=0,64$ e $r=-0,05$ para as áreas-teste 1 e 2 , respectivamente. Ou seja, para a Área-teste 1 os modelos apresentaram uma correlação moderada, entretanto, para a Área-teste 2 não houve correlação ("r" próximo de zero).

Estes resultados podem ser justificados pelas diferentes metodologias utilizadas pelos dois modelos, ressaltando assim as diferentes ponderações (importâncias) relativas das variáveis. No modelo proposto por Crepani et al. (2001) a utilização da média aritmética entre as variáveis pressupõe que todas elas têm a mesma importância para definir o grau de fragilidade. No modelo proposto por Ross (1994) as variáveis têm diferentes ponderações, sendo que o relevo tem uma importância muito superior às demais variáveis para definir o grau de fragilidade.

\section{Modelo Crepani et al. (2001) x Modelo RNA Crepani}

As comparações entre o modelo proposto por Crepani et al. (2001) e o modelo que utiliza a RNA treinada com dados fornecidos por este especialista mostram que houve contraste 
e 08.

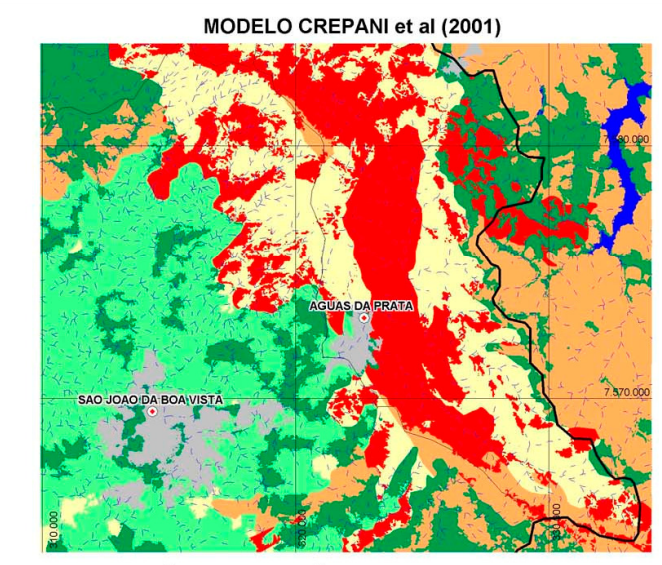

CONVERGÊNCIAS E DIVERGÊNCIAS

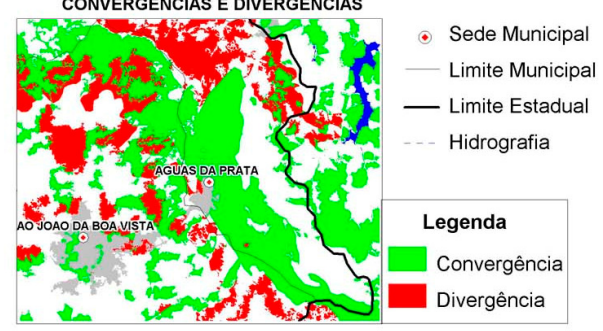

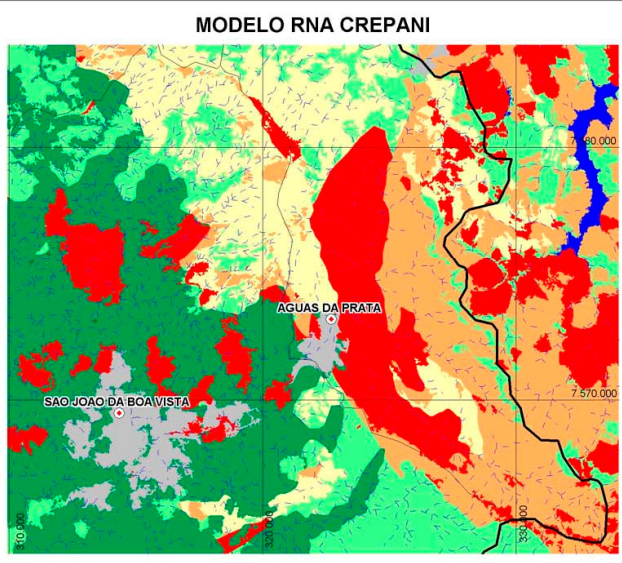

Graus de Fragilidade

Nivel 1

Nivel 2

Nivel 3

Nivel 4

Nivel 5

Área Urbana

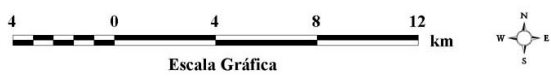

FIGURA 07 - Comparação Modelo Crepani x RNA Crepani - Área-Teste 1

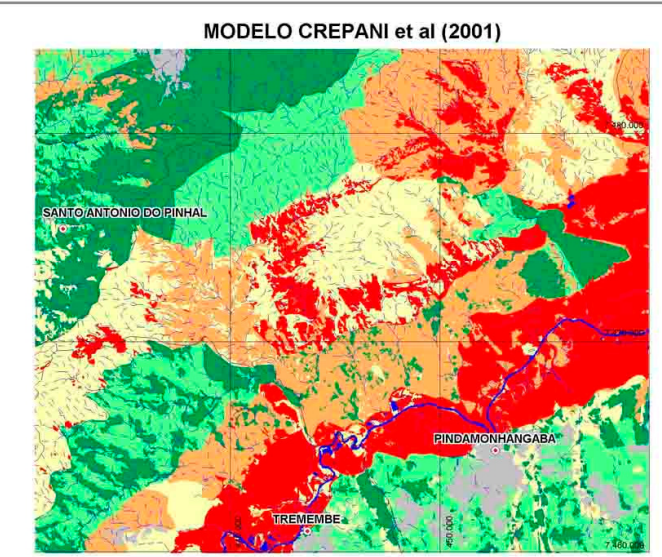

CONVERGÊNCIAS E DIVERGÊNCIAS

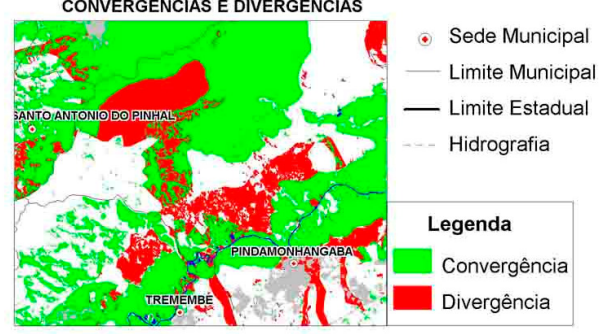

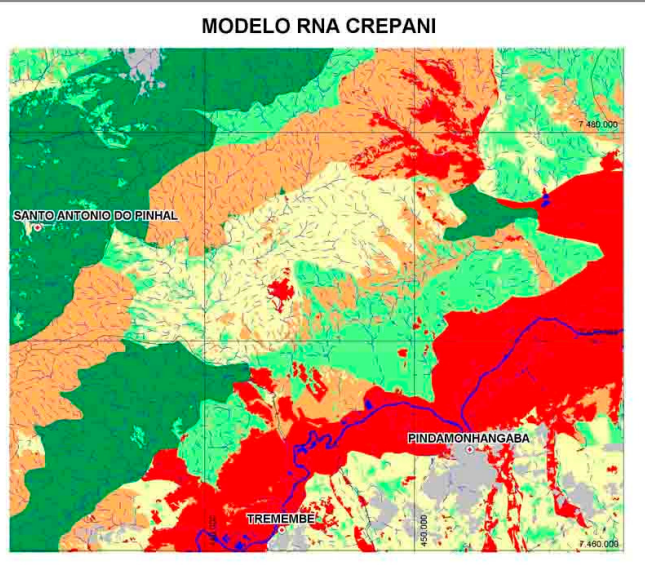

Graus de Fragilidade

Nivel 1

IDivel 2

Nivel 3

Nivel 4

Nivel 5

Área Urbana

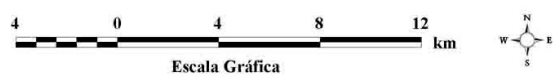

FIGURA 08 - Comparação Modelo Crepani x RNA Crepani - Área-Teste 2 
Estes resultados foram confirmados pelos coeficientes de correlação calculados para verificar o grau de associação entre estes dois modelos. Os coeficientes calculados são $r=$ 0,73 e $r=0,66$ para as áreas-teste 1 e 2, respectivamente. Nestes dois casos, os modelos apresentaram uma correlação moderada.

\section{Modelo Ross (1994) x Modelo RNA Ross}

As comparações entre o modelo proposto por Ross (1994) e o modelo que utiliza a RNA treinada com dados fornecidos por este especialista deixa claro o contraste significativo apresentado pelos resultados da aplicação destes modelos, principalmente na Área-teste 2.

Os coeficientes de correlação calculados para verificar o grau de associação entre estes dois modelos indicaram para a Área-teste 1 um valor de $r=0,26$, e para a Área-teste $2 r=-0,60$. Estes coeficientes demonstram uma fraca correlação entre os modelos na Área-teste 1, e correlação negativa na Área-teste 2, neste caso sugerindo que quando em um dos modelos os valores de fragilidade crescem, no outro, os valores diminuem.

Deve-se lembrar que no modelo proposto por Ross (1994) a variável relevo é determinante para definir o grau de vulnerabilidade, as demais variáveis acabam interferindo muito pouco neste processo.

Já no modelo resultante da RNA treinada com dados deste especialista as ponderações não seguiram o mesmo raciocínio. Neste modelo (RNA Ross), além da declividade dominante, as demais variáveis tiveram ponderações consideráveis, interferindo na determinação do grau de vulnerabilidade, apresentando então classificações bastante distintas do modelo proposto por Ross (1994).

Os contrastes entre as classificações são marcantes, principalmente na Área-teste 2, conforme apresentado nas Figuras 09 e 10. Foram poucas as áreas em que houve convergência dos níveis de fragilidade classificados entre estes dois modelos. As maiores divergências ocorreram principalmente na planície fluvial do Rio Paraíba do Sul, onde essas áreas foram classificadas como Nível 1 pelo modelo proposto por Ross (1994), e Nível 5 pelo modelo gerado pela RNA deste especialista. 


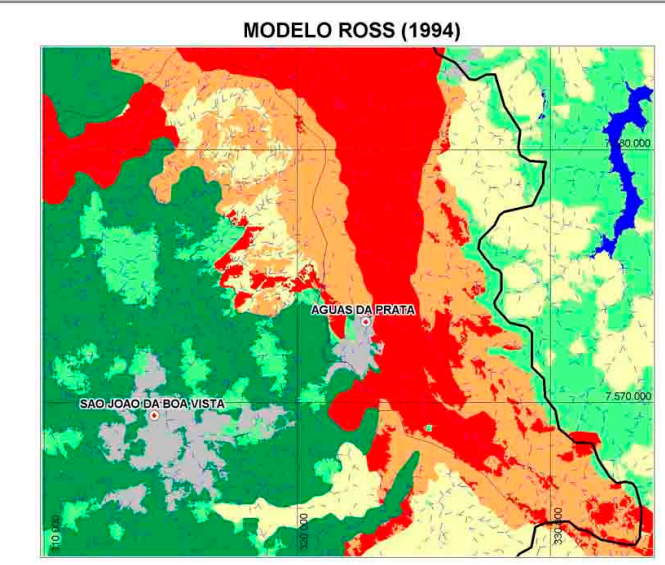

CONVERGÊNCIAS E DIVERGÊNCIAS

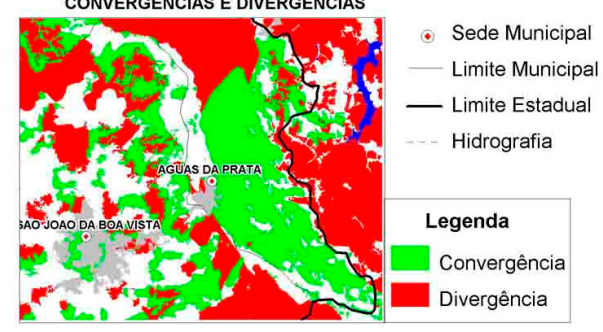

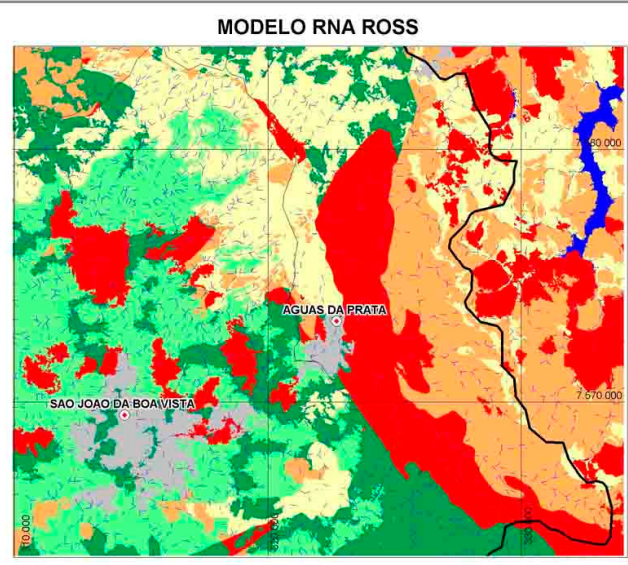

Graus de Fragilidade

Nivel 1

Nível 2

Nivel 3

Nivel 4

Nivel 5

Área Urbana

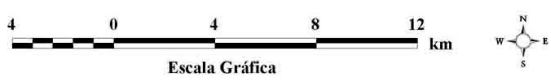

FIGURA 09 - Comparação Modelo Ross x RNA Ross - Área-Teste 1.
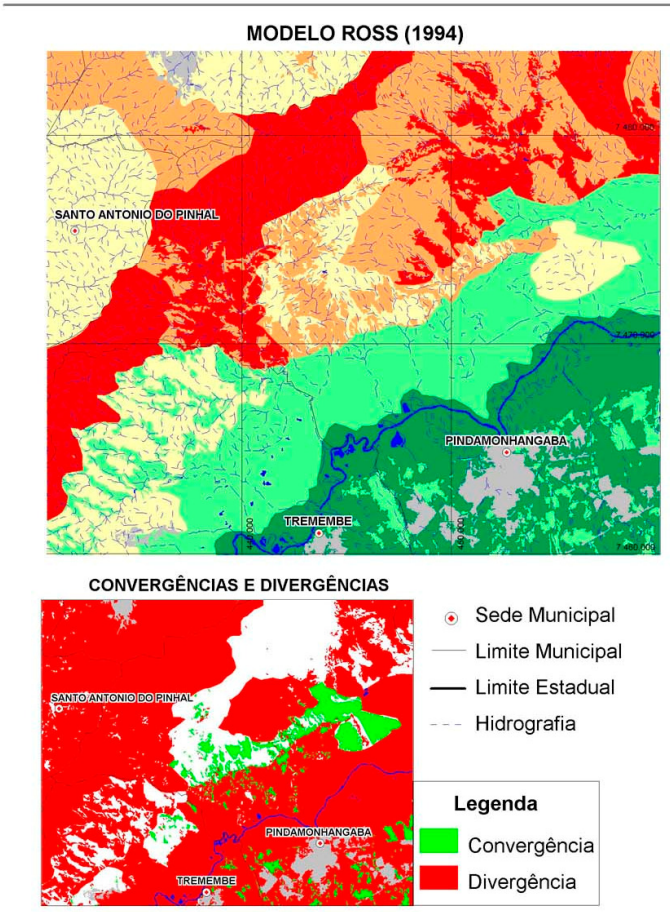

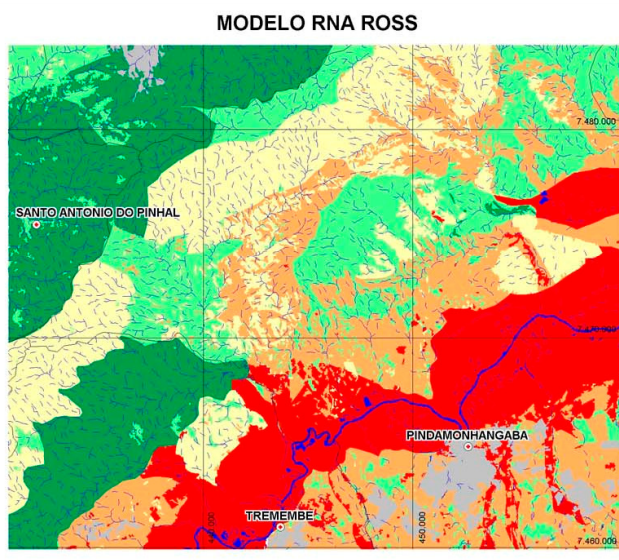

Graus de Fragilidade

Nivel 1

Nível 2

Nivel 3

Nivel 4

Nivel 5

Área Urbana

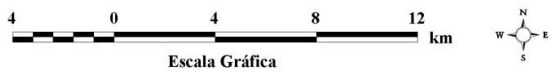

FIGURA 10 - Comparação Modelo Ross x RNA Ross - Área-Teste 2 


\section{Modelo RNA Crepani x Modelo RNA Ross}

Quando comparados os modelos gerados pelas RNAs de Crepani e de Ross observa-se uma grande semelhança entre os resultados apresentados pelos mapas. Estas grandes afinidades entre os modelos são apresentadas nas Figuras 11 e 12.

Conforme observado nos mapas simplificados são poucas as divergências apresentadas entre estes modelos, e a similaridade é bastante significativa nas duas áreas-teste. Os coeficientes de correlação calculados indicaram grau de associação altíssimo entre estes dois modelos, $r=0,97$ tanto para a Área-teste 1 quanto para a Área-teste 2 .
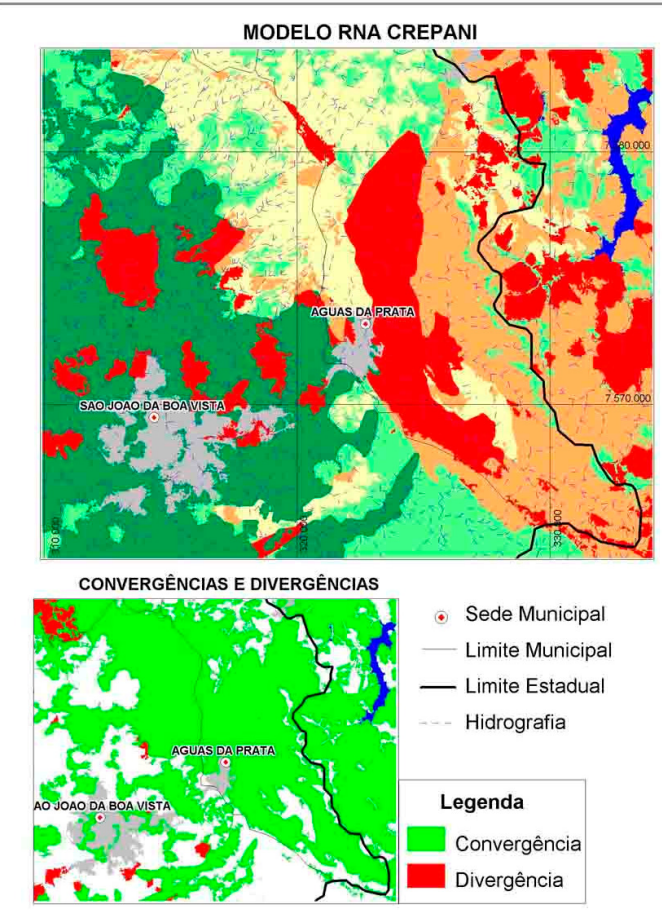
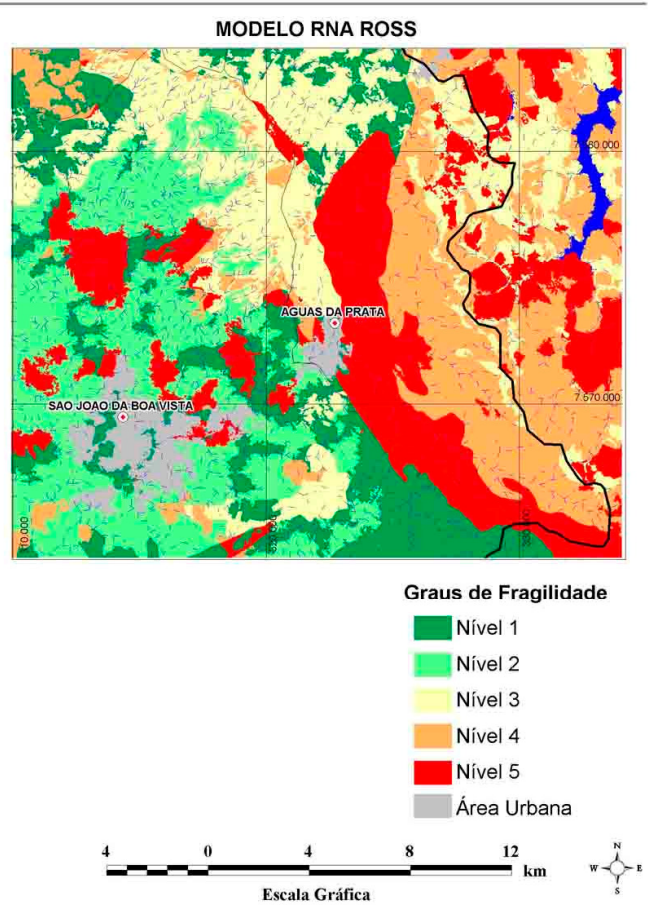

FIGURA 11 - Comparação RNA Crepani x RNA Ross - Área-Teste 1.

Este elevado coeficiente de correlação apresentado entre as RNAs treinadas com dados dos especialistas Crepani e Ross é muito significativo, sugerindo que há uma grande concordância entre os dois especialistas na avaliação da fragilidade.

Estes resultados indicam que os dois especialistas apresentam padrões muito semelhantes de avaliação para hierarquizar as variáveis na complexa questão da vulnerabilidade dos sistemas ambientais. 


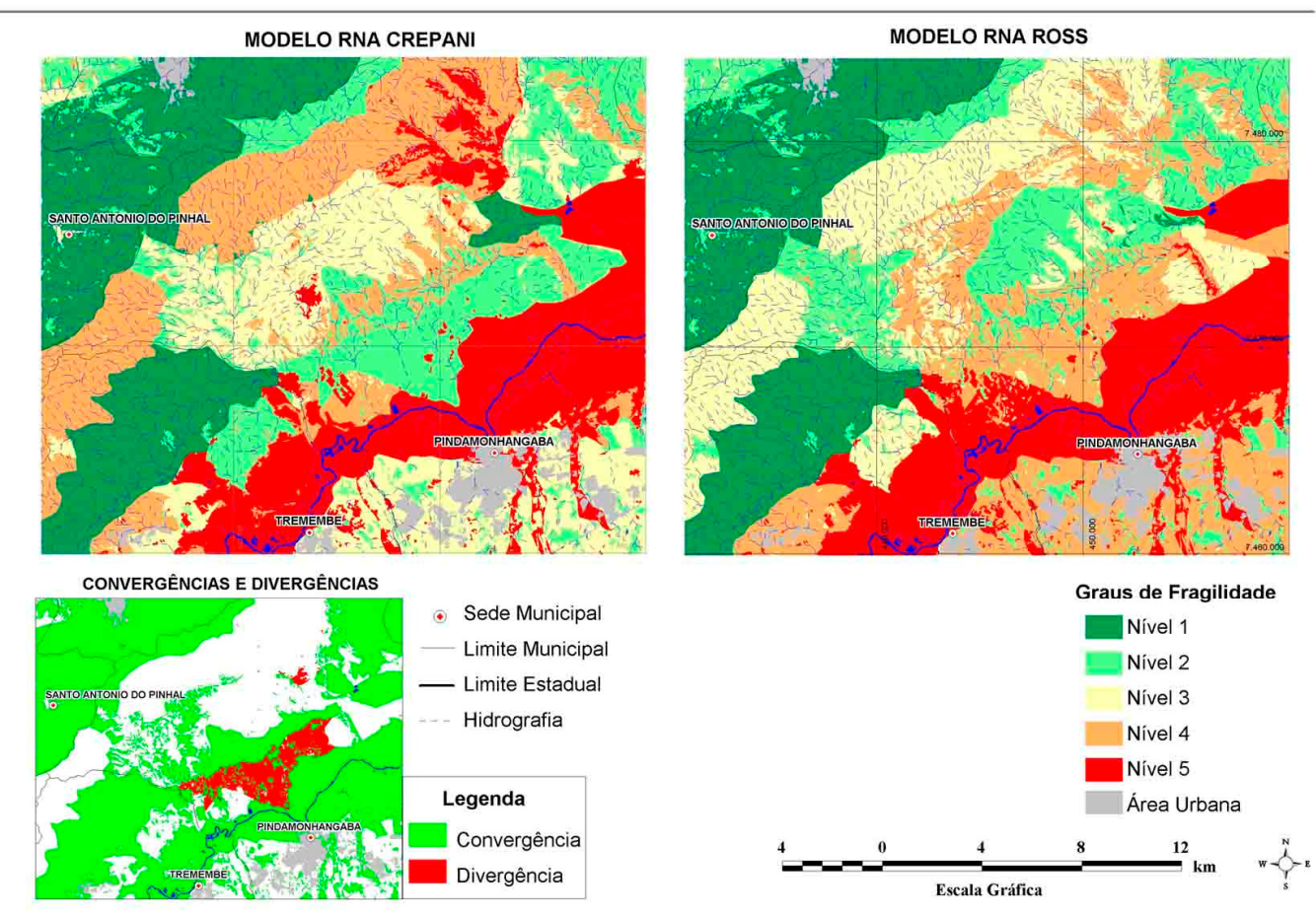

FIGURA 12 - Comparação RNA Crepani x RNA Ross - Área-Teste 2

\section{ANÁLISE DOS RESULTADOS}

Os modelos propostos por Crepani et. al (2001) e por Ross (1994), amplamente utilizados, quando comparados entre si, não apresentaram correlação satisfatória. No entanto, as RNAs treinadas com informações geradas por estes mesmos especialistas apresentam altíssimas correlações, conforme apresentado na Tabela 02.

Tabela 02 - Coeficiente de correlação entre os modelos

\begin{tabular}{lcccc}
\hline \multirow{2}{*}{\begin{tabular}{c} 
Coeficiente $\begin{array}{c}\text { de } \\
\text { Correlação }\end{array}$ \\
\cline { 2 - 5 }
\end{tabular}} & $\begin{array}{c}\text { Modelo Crepani } \\
\text { et al./Modelo } \\
\text { Ross }\end{array}$ & $\begin{array}{c}\text { Modelo Crepani et } \\
\text { al./RNA Crepani }\end{array}$ & $\begin{array}{c}\text { Modelo Ross/ } \\
\text { RNA Ross }\end{array}$ & $\begin{array}{c}\text { RNA Crepani/ } \\
\text { RNA Ross }\end{array}$ \\
\hline $\begin{array}{l}\text { Área-Teste } \\
\mathbf{1}\end{array}$ & 0,64 & 0,73 & 0,26 & 0,97 \\
$\begin{array}{l}\text { Área-Teste } \\
\mathbf{2}\end{array}$ & $-0,05$ & 0,66 & $-0,60$ & 0,97 \\
\hline
\end{tabular}

Os coeficientes de correlação e os mapas gerados pelos resultados dos modelos sugerem algumas conclusões: 
- Resultados dos modelos empíricos são mais dependentes dos cenários, variam muito, dependendo de onde estão sendo aplicados.

- A correlação entre os modelos gerados pelas RNAs dos especialistas aparentemente dependem menos dos cenários.

- RNA Crepani x RNA Ross: Correlação altíssima $r=0,97$

- Modelos Crepani e Ross x RNAs destes especialistas: maior concordância entre as RNAs de Crepani e Ross do que com seus próprios modelos.

Resumidamente estes dados sugerem que os especialistas concordam nos conceitos e no padrão de avaliação das variáveis que compõem os sistemas ambientais, mas discordam na forma de construir os modelos.

Estas constatações reforçam a tese de que estes modelos não refletem os vastos conhecimentos adquiridos pelos especialistas. O modelo não consegue traduzir exatamente estes conhecimentos: há um descompasso entre o modelo proposto e o conhecimento dos especialistas.

Este problema apresentado pelos modelos se justifica, pois a construção de modelos é uma tarefa complexa, na qual é difícil ajustar seus parâmetros para traduzir exatamente a experiência e os conhecimentos adquiridos pelos especialistas.

\section{CONCLUSÕES}

Os resultados apresentados nesta pesquisa dão uma idéia de quão complexa é a modelagem dos sistemas ambientais. O processo da modelagem da fragilidade ambiental é um grande desafio, pois implica em compreender de forma qualitativa e quantitativa a relação entre as variáveis ambientais e a dinâmica extremamente complexa que envolve estas componentes físicas, bióticas e sócio-econômicas.

Diante das dificuldades de se modelar a fragilidade ambiental, entende-se que mesmo havendo um razoável conhecimento qualitativo e empírico da dinâmica do sistema, este entendimento não é facilmente traduzido em modelos matemáticos.

A Rede Neural Artificial (RNA) se mostrou eficiente para fazer essa tradução. Os resultados comprovam a expectativa inicial de que é possível emular, com razoável confiabilidade, o padrão de avaliação de especialistas na definição da fragilidade dos sistemas ambientais. 
Houve eficiência da RNA em reconhecer o padrão de avaliação adotado por todos os especialistas.

Podem ser citadas algumas vantagens e desvantagens das RNAs:

\section{Vantagens da RNA:}

- capacidade em lidar com grande número de informações;

- leva em consideração qualquer número de fatores, por mais insignificantes que sejam os efeitos de cada um deles.

\section{Desvantagens da RNA:}

- ferramenta geralmente não familiar aos geógrafos;

- modelo de fundamentação teórica mais complexo, menos intuitivo para ser compreendido como ferramenta.

Ainda assim, os algoritmos que emulam as RNAs são evidentemente mais complexos, mas de uma complexidade muito menor do que aquela apresentada pelos sistemas ambientais.

Da economia à medicina, todas as áreas do conhecimento têm adotado, em maior ou menor grau, tecnologias cujos princípios detalhados de funcionamento não são familiares aos seus profissionais. O mercado financeiro, por exemplo, aplica diversos modelos preditivos, alguns baseados em redes neurais artificiais, e a medicina faz uso de ressonância magnética como ferramenta de diagnóstico, além de muitos outros exemplos.

Caso a geografia também queira ter a sua disposição ferramentas mais eficientes, ela deve estar preparada para incorporar, sem preconceitos, o que a tecnologia pode oferecer, por mais áridos que sejam os mecanismos internos destes sistemas.

Uma importante contribuição deste trabalho foi ter dado um passo em busca destas novas técnicas, que ainda estão muito longe de terem sido devidamente exploradas na Ciência Geográfica. Técnicas que podem ser às vezes temidas pelos geógrafos, mas necessárias para a evolução deste campo do conhecimento.

\section{REFERÊNCIA BIBLIOGRÁFICA}

ADELMAN, Leonard. (1992) "Evaluating Decision Support and Expert Systems". John Wiley \& Sons. New York. 
CASTRO, Emiliano Gonçalves de. (1998) "Reconhecimento de Padrões em Tomada de

Decisão Utilizando Redes Neurais Artificiais". Trabalho de Conclusão de Curso - Escola Politécnica - USP, São Paulo.

CHAGAS, César da Silva; FERNANDES-FILHO, Elpídio Inácio; VIEIRA, Carlos Antônio Oliveira; CARVALHO-JÚNIOR, Waldir. (2007) "Utilização de Redes Neurais Artificiais para Predição de Classes de Solo em uma Bacia Hidrográfica no Domínio de Mar de Morros". In: XIII Simpósio Brasileiro de Sensoriamento Remoto. INPE, Florianópolis, Santa Catarina.

CHORLEY, Richard J.; HAGGETT, Peter. (1975) “Modelos Físicos e de Informação em Geografia". Rio de Janeiro.

CREPANI, E.; MEDEIROS, J.S.; AZEVEDO, L.G.; DUARTE, V.; HERNANDEZ, P.; FLORENZANO, T. (1996) "Curso de Sensoriamento Remoto Aplicado ao Zoneamento Ecológico-Econômico". INPE, São José dos Campos, SP.

CREPANI, E.; MEDEIROS, J.S.; AZEVEDO, L.G.; DUARTE, V.; HERNANDEZ, P.; FLORENZANO, T; BARBOSA, C.. (2001) "Sensoriamento Remoto e Geoprocessamento Aplicados ao Zoneamento Ecológico-Econômico e ao Ordenamento Territorial". INPE, São José dos Campos, SP.

MEDEIROS, José Simeão. (1999) "Banco de Dados Geográficos e Redes Neurais Artificiais: Tecnologias de Apoio à Gestão do Território". Tese Doutorado - FFLCH.

NAKASHIMA, Myriam. (1999) “Análise dos Processos Erosivos e da Fragilidade Ambiental na Bacia do Keller-PR". Tese de Doutorado, FFLCH, São Paulo.

OPENSHAW, Christine \& OPENSHAW, Stan. (1997) "Artificial Intelligence in Geography". England. 
RODRIGUES, Sílvio Carlos. (1998) “Análise Empírico-Experimental da Fragilidade Relevo-Solo no Cristalino do Planalto Paulistano: Sub-Bacia do Reservatório Billings". Tese de Doutorado FFLCH - USP, São Paulo.

ROSS, Jurandyr Luciano Sanches (1991) - Geomorfologia, ambiente e planejamento Contexto, São Paulo.

ROSS, Jurandyr Luciano Sanches (1994) “Análise Empírica da Fragilidade dos Ambientes Naturais e Antropizados". In: Revista do Departamento de Geografia no8, FFLCH-USP, São Paulo.

ROSS, Jurandyr Luciano Sanches. (1995) “Análise e Síntese na Abordagem Geográfica da Pesquisa para o Planejamento Ambiental" Revista do Departamento de Geografia n?9, FFLCH-USP, São Paulo.

ROSS, Jurandyr Luciano Sanches. (2000) "Zoneamento Ecológico-Econômico - ZEE - Brasil". In: Workshop - Metodologia de Zoneamento Ecológico-Econômico para a Região Nordeste, Fortaleza, Ceará.

SPÖRL, Christiane. (2001) "Análise da Fragilidade Ambiental Relevo-Solo com Aplicação de Três Modelos Alternativos nas Altas Bacias do Rio Jaguari-Mirim, Ribeirão do Quartel e Ribeirão da Prata". Dissertação de Mestrado FFLCH - USP, São Paulo.

SPÖRL, Christiane \& ROSS, Jurandyr Luciano Sanches. (2004) "Análise Comparativa da Fragilidade Ambiental com Aplicação de Três Modelos". GEOUSP, no15, FFLCH-USP, São Paulo.

SPÖRL, Christiane. (2004) "Modelo de Fragilidade Ambiental Utilizando Redes Neurais Artificiais" II SEPEGE, FFLCH-USP, São Paulo.

SPÖRL, Christiane. (2006) "Metodologia para Elaboração de Modelos de Fragilidade Ambiental Utilizando Redes Neurais Artificiais" III SEPEGE, FFLCH-USP, São Paulo. 
SPÖRL, Christiane. (2007) "Metodologia para Elaboração de Modelos de Fragilidade Ambiental Utilizando Redes Neurais Artificiais" Tese Doutorado FFLCH-USP, São Paulo. 